IJIEF: International Journal of Islamic Economics and Finance

Vol. 1 (2), pg 75-94, January 2020

\title{
Fintech and Islamic Finance: Literature Review and Research Agenda
}

\author{
Rashedul Hasan \\ INTI International University, Malaysia, hasanaiub05@gmail.com \\ M. Kabir Hassan \\ University of New Orleans, United States, mhassan@uno.edu \\ Sirajo Aliyu \\ Federal Polytechnic Bauchi, Nigeria, sirajoaliyu@yahoo.com
}

Article History

Received: December 23, 2019 Revised: January 7, 2020 Accepted: January 11, 2020

\begin{abstract}
Fintech revolution started with the introduction of credit cards in 1960 and have been revolutionized with blockchain technologies. Integration of Fintech based solution with Islamic finance has gained interest among academics. However, the lack of literature evidence on this issue has motivated us to conduct a systematic literature review on Islamic Fintech. We have identified fourteen documents relevant to the context of the study and conducted the content and thematic analysis. An extensive review of past literature allows us to identify Shari'ah compliance as one of the major challenges for the growth of Islamic fintech. In addition, we conclude that Islamic fintech might pose challenges for Islamic Financial Institutions (IFIs) in terms of operational efficiency, customer retention, transparency and accountability. We contribute by providing insights on the challenges faced by the Islamic finance industry toward integrating Fintech based solutions with reference to past studies and indicate areas for future studies that could reduce the gaps in Islamic Fintech literature.
\end{abstract}

Keywords: Islamic Fintech, Blockchain. Bitcoin, Cryptocurrency, Shari'ah. JEL Classification: 030,033

@ IJIEF 2020 published by Universitas Muhammadiyah Yogyakarta, Indonesia All rights reserved

DOI:

https://doi.org/10.18196/ijief.2122
Web:

http://journal.umy.ac.id/index.php/ijief/article/view/7823

Citation:

Hasan, R., Hassan, M. K. and Aliyu, S. (2020). Fintech, Blockchain and Islamic Finance: Literature Review and Research Agenda. IJIEF: International Journal of Islamic Economics and Finance, 3(1), 75-94. DOI: https://doi.org/10.18196/ijief.2122 
Hasan, Hassan, \& Aliyu | Fintech, Blockchain and Islamic Finance: Literature Review and Research Agenda

\section{Introduction}

Fintech is characterized as the financial services of the twenty-first century (Todorof, 2018). Recent growth in the mobile applications and usage of website among users have hinted the inclusion of Fintech revelation among the global financial sector. Fintech development has revolutionized the financial service industry with the use of computer-based technologies. Hence, Fintech is often referred to as the blend of digital innovation and financial services with an aim to improve the efficiency of the financial service industry. Zavolokina, Dolata and Schwabe (2017), therefore, regarded Fintech as the marriage of technological innovation and finance which has the ability to elevate the financial service industry to a new height.

Recent studies have indicated several advantages of the Fintech revolution in the financial service industry. In addition to the disruption of traditional financial markets (Lee \& Shin, 2018), Fintech can ensure operating efficiency, improve (Gomber, Kauffman, Parker, \& Weber, 2018) customer-centric services and lead to better transparency in the financial service sector. Loo (2018) is more optimistic about the role of Fintech in the financial service industry and believe that this revolution can positively improve the growth of the financial service industry by reducing the probability of a financial crisis. Such results can be achieved if financial service providers are allowed to compete freely.

Islamic finance, developed on Shari'ah principles, can be benefitted from the application of Fintech technologies. However, recent studies (Abu-Bakar, 2018; Abubakar, Ogunbado, \& Saidi, 2018; Biancone, Secinaro, \& Kamal, 2019; Todorof, 2018) have explored on the computability issues of Fintech based solutions for Islamic finance industry. While there are views both for and against Shari'ah compliance nature of Fintech products, various applications of Fintech for the Islamic finance industry cannot be denied. Elasrag (2019) has highlighted the use of smart contracts to ensure products or services of the Islamic financial industry as Shari'ah complaint.

The use of blockchain-based solutions can allow Islamic banks to control the increasing cost of transactions and can help to manage profit-sharing agreements. Benefits of blockchain in creating smart contracts have already attracted many financial enterprises. Abojeib and Habib (2019) highlighted the possible use of blockchain for a charitable purpose, especially in the collection of zakat. A similar application of Fintech can also improve the utility of waqf. Tieman and Darun (2017) reflected on the importance of blockchain as a solution for the halal industry problem.

IJIEF: International Journal of Islamic Economics and Finance, 3(1), 75-94 | 76 
Hasan, Hassan, \& Aliyu | Fintech, Blockchain and Islamic Finance: Literature Review and Research Agenda

As a result, Islamic Fintech industry has emerged robustly since 2010. The industry has been estimated at USD 2.4 trillion in 2017 and is projected to grow at 7.7 per cent CAGR to reach USD 3.8 trillion in 2023 (Dubai Islamic Economy Development Centre, 2018). In general, the core impact of Fintech technology for Islamic fiancé industry is divided into three categories. First, technologies such as Artificial Intelligence (AI) and Big Data that aims at greater automation from insights of activity. The second group of technologies are focusing on disintermediation leading to open access to services and include P2P finance and mobile banking.

The final group consist of greater decentralization and security and include blockchain and cloud-based technologies. However, we have witnessed a lower level of adoption of big data and Al-based solutions for wealth management. Fintech has yet to mark its presence in the Takaful industry as compared to the high degree adoption in the Islamic banking industry. Therefore, we have conducted this study to explore the possible application of Fintech in Islamic finance. We provide a systematic review of related literature to explore challenges faced by Islamic Fintech and contribute by highlighting research agenda that could improve the integration of Fintech and Islamic finance.

\section{Literature Review}

Fintech has proven to be a beneficial innovation for the financial service industry and has improved the level of financial inclusion by reaching to a diverse group of customers. While the concept of Fintech is new, it has already made its mark in the Islamic finance industry. The development of Islamic Fintech has paved the way for developing innovative Shari'ah compliant products for the Islamic consumers which could pave the way for a greater competitive edge for the Islamic finance sector. It is important to highlight that Islamic Fintech is different than the conventional Fintech due to the requirements of Shari'ah compliance. However, the emergence of Fintech solution has provided Islamic financial institutions (IFIs) with greater opportunities to improve their infrastructure and product offering (Jamil \& Seman, 2019). As such, research on the application of Fintech in the Islamic finance sector has increased in recent years (Abojeib \& Habib, 2019; Biancone et al., 2019; Jamil \& Seman, 2019).

Baber (2019) has made a significant contribution by studying the contribution of Fintech and crowdfunding on customer retention among Islamic banks in Malaysia and the United Arab Emirates. Malaysia was selected for such analysis due to Malaysia receiving the highest score in the Islamic Finance Country Index. The United Arab Emirates was chosen for the

IJIEF: International Journal of Islamic Economics and Finance, 3(1), 75-94 | 77 
Hasan, Hassan, \& Aliyu | Fintech, Blockchain and Islamic Finance: Literature Review and Research Agenda

comparative analysis as the country has the largest market share in Islamic finance. Results provided though the survey of 535 customers of selected Islamic banks indicate that Fintech based services do not contribute toward improving customer retention among Islamic banks. However, crowdfunding based services have a positive impact on customer retention for Islamic banks operating in Malaysia and the UAE. These findings contradict with the findings of Aisyah (2018) who report that Islamic Fintech can improve financial dealings, service offerings and convenience leading to higher customer loyalty for Indonesian banks.

As mentioned earlier. Shari'ah compliance takes a center stage in the possible integration of fintech with Islamic finance. Islamic Fintech firms have made a good attempt to ensure that their business models are compliant with Shari'ah requirements by adhering to universally applicable Shari'ah standards and going through a regulatory audit. However, Shari'ah compliance has remained a wide research area for Islamic Fintech. Biancone et al. (2019), for example, explored the Shari'ah compliant business models of crowdfunding and Fintech firms and conclude that Shari'ah compliant crowdfunding invests in halal products, shares the risk of investment and does to charge interest. Biancone \& Radwan (2019) further emphasized the importance of the prohibition of interest for the acceptance of Fintech based business models as Shari'ah compliant. Fintech also allows IFIs to become more transparent by creating a direct link between the customer and the investors from the very beginning of the project.

Past literature has focused primarily on the Shari'ah aspect of bitcoin, a popular cryptocurrency. The first view toward cryptocurrency is that it is not permissible in Islam. According to the Grand Mufti of Egypt, Shaykh Shawki Allam, bitcoin has been linked to illegal activities and have been used to invest in non-Shari'ah compliant purposes (Abu-Bakar, 2018). The fatwa provided by the Turkish Government states that the buy and sell of virtual currencies are not complying the requirements of Shari'ah as it is affected by the elements of speculation (excessive Gaharar).

The fatwa centre of Palestine is in line with the views of the Turkish government and have declared bitcoin and cryptocurrencies as haram (nonpermissible). The primary reason behind such a view can be attributed to the lack of monitoring and ability to trace the issuer of bitcoin which makes it untrustworthy and unreliable. Sheikh Imran (2017) views that intrinsic value should be considered while evaluating money and bitcoin does not pass the test of intrinsic value. Shaykh Haitam also commented that bitcoin and any other forms of cryptocurrencies should be prohibited as they are not backed by anything and also created out of nothing. (Abubakar et al., 2018).

IJIEF: International Journal of Islamic Economics and Finance, 3(1), 75-94| 78 
Hasan, Hassan, \& Aliyu | Fintech, Blockchain and Islamic Finance: Literature Review and Research Agenda

However, some scholars have an opposite view toward cryptocurrencies and rule bitcoin as a complaint to Shari'ah. Oziev and Yandiev (2018), for example, do not find any evidence that makes bitcoin contradict to Shari'ah and indicate that high instability attached to the exchange rate of bitcoin acquired for saving purpose may have excessive risk (Gharar) and speculation (Maysir). Therefore, elimination of the volatility of bitcoin exchange rate can improve its Shari'ah compliance feature and it can be done by adjusting it with major currencies of the world.

Bakar (2018) also believes that bitcoin complies with Shari'ah and recommends the application of blockchain-based solutions to reduce the allegation that bitcoins are being used for money-laundering and other forms of illegal activities. Kahf (2015) concludes bitcoin like any other currency within its community and thus the exchange of bitcoin with their currencies should be subject to similar conditions of currency exchange. Such condition can include but are not limited to the location of exchange and prohibition of speculation related to such exchange.

\section{Methodology}

Fintech is a recent innovation and limited literary evidence exist on its integration in the Islamic finance industry. Therefore, we have made an attempt to conduct a systematic review of the possible application of Fintech solution toward improving the attractiveness and Shari'ah compliance of products offered by the Islamic finance industry. We have used the literature review process proposed by Stechemesser and Guenther (2012). There are three stages in the literature review process applied by Stechemesser and Guenther (2012).

The first stage includes establishing the research objective and collection of papers from databases. This stage allows us to identify relevant literature focusing on Islamic Fintech. We have included both theoretical and conceptual papers in our literature review process. The primary objective of this research is the identification of a research agenda to explore possible ways of integration of Fintech based solution in the Islamic finance industry. Therefore, we have used several keywords in our database which include "Fintech", "Bitcoin", "Blockchain", "Islamic Finance", "Shari'ah". We have used Elsevier, Emerald, Scopus, Springer and Google Scholar databases for the literature search process. The initial search resulted in the collection of 58 paper.

In the second stage, we have established screening criteria to identify relevant papers for the content analysis process. We have considered the

IJIEF: International Journal of Islamic Economics and Finance, 3(1), 75-94 | 79 
Hasan, Hassan, \& Aliyu | Fintech, Blockchain and Islamic Finance: Literature Review and Research Agenda

limited supply to the relevant publication of journal articles on Fintech and Islamic finance, and thus, included journal articles, books, reports published by governmental and professional bodies, books, book chapters and conference proceedings. Following the findings of Morrison et al. (2012), we have restricted our study to papers published in English. Both empirical and conceptual articles are included in the review process. Finally, 20 documents were found relevant and are used in the literature review process.

In the final stage, we have applied a review protocol proposed by Krippendorff (2013) to analyze the suitability of the selected documents for the content analysis. Documents published before 2013 are not selected for the content analysis process. We have also reviewed the citation score of all documents to improve the reliability of findings presented through the literature review process. Application of these inclusion and exclusion criteria have resulted in the selection of 16 documents that meet all requirements established by the review protocol. Brief description of the documents is provided in Table 1. 
Hasan, Hassan, \& Aliyu | Fintech, Blockchain and Islamic Finance: Literature Review and Research Agenda

Table 1. Key findings on Islamic Fintech

\begin{tabular}{|c|c|c|c|}
\hline No & Author and Date & Document Type & Findings \\
\hline 1 & Khan (2017) & Article & $\begin{array}{l}\text { Cryptocurrency, one of the latest creations of blockchain } \\
\text { technology, has not been designed with Islamic markets in } \\
\text { mind. }\end{array}$ \\
\hline 2 & Todorof (2018) & Article & $\begin{array}{l}\text { Introduction of Fintech in Islamic banking has the } \\
\text { potential to improve competitiveness and inclusiveness. } \\
\text { However, it would require an increasing number of } \\
\text { products and services that are offered at lower prices } \\
\text { which can reduce the credit gap existing among various } \\
\text { Muslim countries. }\end{array}$ \\
\hline 3 & Abu-Bakar (2018) & Working paper & $\begin{array}{l}\text { Bitcoin is permissible in principle as it is traded on global } \\
\text { exchanges and accepted worldwide. }\end{array}$ \\
\hline 4 & $\begin{array}{l}\text { Lacasse et al. } \\
(2017)\end{array}$ & Article & $\begin{array}{l}\text { This paper made a qualitative enquiry about the ability of } \\
\text { bitcoin technology and smart contracts to support and } \\
\text { enhance the transparency of the Islamic finance industry. }\end{array}$ \\
\hline 5 & Elasrag (2019) & Article & $\begin{array}{l}\text { This paper provides various applications of blockchain in } \\
\text { the Islamic finance industry. }\end{array}$ \\
\hline 6 & $\begin{array}{l}\text { Dubai Islamic } \\
\text { Economy } \\
\text { Development } \\
\text { Centre (2018) }\end{array}$ & Report & $\begin{array}{l}\text { This report provides valuable insights on the global } \\
\text { Fintech ecosystem and Islamic Fintech ecosystem. }\end{array}$ \\
\hline 7 & $\begin{array}{l}\text { Abojeib and Habib } \\
\text { (2019) }\end{array}$ & Book Chapter & $\begin{array}{l}\text { Blockchain and smart contract technologies can help waqf } \\
\text { institutions to improve their governance structure and } \\
\text { ensure Shari'ah compliance. }\end{array}$ \\
\hline 8 & $\begin{array}{l}\text { Lacasse et al. } \\
(2018)\end{array}$ & Article & $\begin{array}{l}\text { A qualitative research framework is adopted to explore } \\
\text { the compatibility of the blockchain monitoring process for } \\
\text { the Islamic banking industry. }\end{array}$ \\
\hline 9 & Muedini (2018) & Article & $\begin{array}{l}\text { Bitcoin and other cryptocurrencies are providing better } \\
\text { solutions to ensure Shari'ah compliance of products } \\
\text { offered by Islamic financial industry. }\end{array}$ \\
\hline 10 & Meera (2018) & Article & $\begin{array}{l}\text { Gold-backed cryptocurrencies are compliant with Shari'ah } \\
\text { and are becoming more desirable among Islamic investor. }\end{array}$ \\
\hline 11 & $\begin{array}{l}\text { Abubakar et al. } \\
\text { (2018) }\end{array}$ & Article & $\begin{array}{l}\text { Muslim scholars believe that bitcoin is Shari'ah compliant } \\
\text { and therefore may be used under certain conditions. }\end{array}$ \\
\hline 12 & $\begin{array}{l}\text { Muneeza et al. } \\
\text { (2018) }\end{array}$ & Article & $\begin{array}{l}\text { Bitcoin technology can help mitigate current challenges } \\
\text { faced by crowdfunding platforms to promote financial } \\
\text { inclusion. }\end{array}$ \\
\hline 13 & $\begin{array}{l}\text { Irwin and Milad } \\
\text { (2016) }\end{array}$ & Article & $\begin{array}{l}\text { Presence of Bitcoin ATMs and exchanges at countries with } \\
\text { a significant number of foreign fighters join ISIS in the } \\
\text { Middle East can present a significant risk for the platform. }\end{array}$ \\
\hline 14 & Evans (2015) & Article & $\begin{array}{l}\text { Bitcoin system is more appropriate for Islamic banking } \\
\text { industry than interest-backed central bank fiat currency. }\end{array}$ \\
\hline 15 & $\begin{array}{l}\text { Abybakar, Hassan } \\
\text { and Haruna }\end{array}$ & Article & $\begin{array}{l}\text { Crypto currencies provide benefits over gold and can } \\
\text { make significant impact in mitigating inflation. }\end{array}$ \\
\hline 16 & $\begin{array}{l}\text { Haruna, Abubakar } \\
\text { and Hassan }\end{array}$ & $\begin{array}{l}\text { Conference } \\
\text { Paper }\end{array}$ & $\begin{array}{l}\text { Crypto currencies can provide an efficient medium of } \\
\text { exchange if backed by precious metal such as gold and } \\
\text { silver. }\end{array}$ \\
\hline
\end{tabular}

Source: Author's Own

IJIEF: International Journal of Islamic Economics and Finance, 3(1), 75-94 | 81 
Hasan, Hassan, \& Aliyu | Fintech, Blockchain and Islamic Finance: Literature Review and Research Agenda

\section{Results}

\subsection{Islamic Fintech Landscape and Ecosystem}

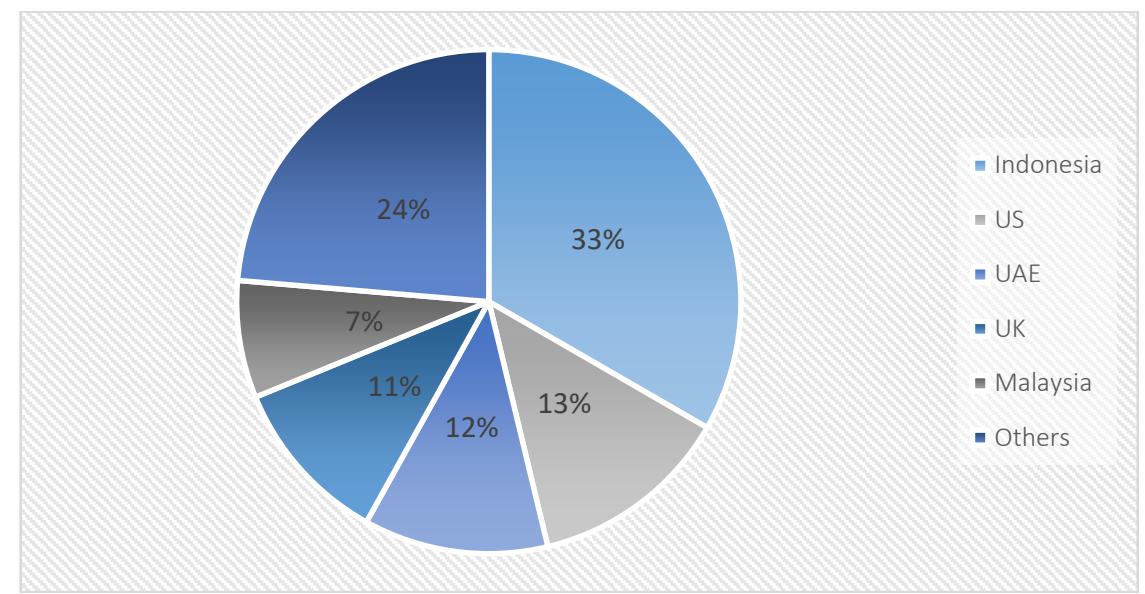

Figure 1. Number of Islamic Fintech Startups by country

Source: Dubai Islamic Economy Development Centre (2018)

According to the Dubai Islamic Economy Development Centre (2018), a total number of Islamic Fintech startups delivering customer-facing financing solutions globally are 93 as of 2018. Figure 1 provides the geographic distribution of Islamic Fintech startups and Indonesia secure the top spot with 33 per cent of the Islamic Fintech startups. However, the number of global Fintech firms has increased to 7,500 with a value of USD 58 billion in 2018. Islamic Fintech has substantial room for growth and concentrated efforts are required from government entities and financial investors toward reducing the gaps in Islamic Fintech ecosystem.

We provide the list of popular Islamic Fintech startups in Table 2. It is evident that Islamic fintech firms have evolved and has been providing services in a wide variety of areas. Indonesia based Invesporperti and Singapore based Ethics has become popular by providing Shari'ah compliant crowdfunding platform for property investment. Kaptal Bost, on the other hand, focuses on financial inclusion of SMEs and provide a crowdfunding platform that follows Shari'ah standards. Malaysia has become a leader in Islamic Fintech development and we provide more detail in the later segment of the paper. In Table 2, we highlight two Islamic Fintech firm providing a wide variety of Fintech services for a wide group of stakeholders. 
Hasan, Hassan, \& Aliyu | Fintech, Blockchain and Islamic Finance: Literature Review and Research Agenda

Table 2. Islamic Fintech startups in selected countries

\begin{tabular}{|c|c|c|c|}
\hline No & $\begin{array}{l}\text { Name of the Islamic } \\
\text { Fintech Firm }\end{array}$ & Country & Major activity \\
\hline 1 & Invesproperti.id & Indonesia & $\begin{array}{l}\text { Property investment using Shari'ah compliant } \\
\text { crowdfunding platform. }\end{array}$ \\
\hline 2 & Ethis & Singapore & $\begin{array}{l}\text { The first Islamic crowdfunding platform for } \\
\text { property investment. }\end{array}$ \\
\hline 3 & Kapital Boost & Singapore & Islamic crowdfunding platform focusing on SMEs. \\
\hline 4 & ATA Plus & Malaysia & $\begin{array}{l}\text { The first equity crowdfunding platform in } \\
\text { Malaysia. }\end{array}$ \\
\hline 5 & MyFinB & Malaysia & Big Data \& Analytics using Al for Islamic banks. \\
\hline 6 & Invoice Wakalah & Pakistan & $\begin{array}{l}\text { Shari'ah compliant peer-to-peer online lending } \\
\text { platform. }\end{array}$ \\
\hline
\end{tabular}

\subsection{Islamic Fintech in the Banking Industry}

Islamic banking products suffer from high prices as compared to their conventional counterparts (Todorof, 2018) which are attributed to their inability to reduce the rate of non-performing loan (Beik \& Arsyianti, 2008) and tendency to maintain a higher portion of the equity in the debt-equity ratio (Iqbal, 2012). In such a situation, Islamic banks can improve their product offerings by incorporating Fintech-based solutions. It is expected that the integration of Fintech-based solutions could enhance the Shari'ah compliant feature of Islamic banking products and make it cheaper. As such, Islamic banking products will receive much-required attention from the Western Fintech industry. Recent Fintech platforms using Blockchain technology and backed by gold are found to be Shari'ah-compliant according to the Accounting and Auditing Organization for Islamic Financial Institutions (AAOIFI). Therefore, one of the agenda for future research could focus on the identification of various instruments that could be applied to the Islamic finance industry.

There has been a growing consensus among researchers that consumer awareness regarding various types of Fintech based services offered by IFIs has increased in recent years. Saad and Fisol (2019) explore the willingness of potential customers to use Fintech services offered by IFIs using a qualitative research design and conclude that awareness theory is suitable to explain the behaviour toward Fintech based services offered by IFIs. The theory of reasoned action (Ibrahim, Fisol, \& Haji-Othman, 2017) and the theory of planned behaviour (Khan \& Ismail, 2011) has also been adopted to explain the attitude toward Fintech based services among various stakeholder groups. 
Hasan, Hassan, \& Aliyu | Fintech, Blockchain and Islamic Finance: Literature Review and Research Agenda

The emergence of Fintech and increase of customer awareness toward Fintech based services could create new challenges for IFIs. Irfan and Ahmed (2019) indicate that Fintech can become an alternative of IFls by creating a non-bank intermediary platform. Currently, crowdfunding based platforms are working on such principled by collaborating with IFIs. However, the growth of crowdfunding platform in providing financial access to various groups of consumers regarded as risky by traditional banking channel might create more opportunities for these platforms to serve as an alternative to the banking channel. We should remember that structural constraints and high-margin investment banking services have paved the way for the development of Fintech industry. Fintech platform operating within the boundaries of Shari'ah does not come with the shareholder and regulatory constraints associated with a traditional bank, conventional or Islamic, and thus can be more niche in their offering.

\subsection{Islamic Fintech Development in Malaysia}

Malaysia has made significant development in the Fintech sector. As of 2019, the country has witnessed the development of 198 Fintech firms, providing services in a wide variety of sectors including electronic payment gateways, blockchain and cryptocurrencies, crowdfunding, online peer-to-peer lending platforms and artificial intelligence. There have been significant improvements in the Islamic Fintech largely contributed by the growth of the Islamic finance sector. We introduce six Islamic Fintech firms operating in Malaysia in Table 3.

Ethics Kapital is one of the earlier crowdfunding platforms that comply with Shari'ah standards. The crowdfunding platform has an operation in fifty-nine countries and focuses primarily on financing housing projects as a means to combat poverty-stricken demographics in Indonesia and Malaysia. The management team of Ethis is divided into founders, advisors, global partners and team. The business model, structure, process and documentation have been reviewed by scholars of FSAC Shari'ah Committee and the panel find their structure and mechanism follows the requirements of Mudarabah structure. The undergoing projects are also found to be Shari'ah compliant. Ethis has made a significant contribution to sustainable development as a participant of the United National Global Compact (EthicsCrowd, 2019).

As-Sidq serves as an online financing platform. Products offered by As-Sidq include personal financing and credit cards which are free from elements prohibited in Shari'ah, i.e. interest (riba), uncertainty (gharar), gambling (gharar) or immoral practices (zulm). The platform has disbursed over 37 billion ringgit worth of Shari'ah compliant financing among 400,000

IJIEF: International Journal of Islamic Economics and Finance, 3(1), 75-94 | 84 
Hasan, Hassan, \& Aliyu | Fintech, Blockchain and Islamic Finance: Literature Review and Research Agenda

Table 3. Islamic Fintech Firms in Malaysia

\begin{tabular}{lll}
\hline No & Name of Islamic Fintech & Major Activities \\
\hline 1 & Ethis Kapital & Peer-to-peer lending platform. \\
2 & As-Sidq & $\begin{array}{l}\text { As-Sidq provides a fundraising platform which is } \\
\text { approved by twenty financial institutions in Malaysia. }\end{array}$ \\
3 & Finterra & $\begin{array}{l}\text { Finterra provides cloud-based financial services. } \\
4\end{array}$ \\
5 & Global Sadaqah & Donation-based crowdfunding platform. \\
6 & Wakaful & Payment gateway which follows Shari'ah standards. \\
\hline
\end{tabular}

Source: Fintech Malaysia

applicants through the participation of more than fifty Islamic financial institutions (As-Sidq, 2020). Unlike As-Sidq, Finterra operates using blockchain technology to provide cloud-based financial services and has operations in India, Hong Kong, Malaysia, Singapore and the United Arab Emirates. Services offered by FInterra include blockchain consulting, token development, software and blockchain development. FInterra has grown rapidly since its establishment in 2017, the platform has over 700,000 members to their digital wallet and made 1 billion tokens available which can be traded by the public.

Global Sadaqah provides a donation-based crowdfunding platform which allows members to conduct charitable deeds and provide Sadaqah, Zakat and Waqf to credible partners. The crowdfunding platform complies with Islamic Digital Economy (IDE) standards which ensure Shari'ah compliance of their business operations. PayHalal, a platform under Souqa Fintech Sdn Bhd, also provides similar services. Finally, Waqaful operated on the basis on waqf principles and provides a one-stop digital solution which can be used by individuals, businesses and specific communities. The platform is contributing to sustainable development by ensuring well-being among community members and is working toward reducing inequalities by utilizing blockchain technologies.

\subsection{Islamic Fintech case studies}

Case 1: Ethical and Shari'ah compliant investing

Wahed Invest is a digital platform that provides ethical investment opportunities to investors. The platform requires investors to open an account before making an investment decision. A minimum deposit of USD 100 is required while opening the account. Investors of Wahed Invest can invest in a diversified portfolio that includes global stock, emerging marker

IJIEF: International Journal of Islamic Economics and Finance, 3(1), 75-94 | 85 
Hasan, Hassan, \& Aliyu | Fintech, Blockchain and Islamic Finance: Literature Review and Research Agenda

Table 4: Portfolio of Wahed Invest

\begin{tabular}{|c|c|c|c|}
\hline No & Portfolio & Description & Past performance \\
\hline 1 & $\begin{array}{l}\text { Global } \\
\text { Stocks }\end{array}$ & $\begin{array}{l}\text { These stocks consist of stock from developed markets. It } \\
\text { follows a large-cap value and is diversified across industries } \\
\text { and geography. }\end{array}$ & $\begin{array}{l}162 \text { per cent } \\
\text { increase in } 2019 \\
\text { compared to } 2010 .\end{array}$ \\
\hline 2 & $\begin{array}{l}\text { Emerging } \\
\text { market } \\
\text { stocks }\end{array}$ & $\begin{array}{l}\text { Investors requiring geographic diversification and growth can } \\
\text { select this portfolio. However, this portfolio consists of a riskier } \\
\text { asset class as compared to global stocks. Emerging market } \\
\text { stocks include companies operating in emerging markets and } \\
\text { following Islamic investment principles. }\end{array}$ & $\begin{array}{l}102 \text { per cent } \\
\text { increase in } 2019 \\
\text { compared to } 2010 .\end{array}$ \\
\hline 3 & $\begin{array}{l}\text { Sukuk or } \\
\text { Islamic } \\
\text { bond }\end{array}$ & $\begin{array}{l}\text { Sukuk provides ownership of the underlying asset and free of } \\
\text { interest. Both asset-based and asset-backed Sukuk are } \\
\text { included in the portfolio. }\end{array}$ & $\begin{array}{l}51 \text { per cent } \\
\text { increase in } 2019 \\
\text { compared to } 2010 .\end{array}$ \\
\hline 4 & Gold & $\begin{array}{l}\text { Gold historically has a low correlation with stocks and bonds } \\
\text { and has the potential for long-term capital appreciation. It can } \\
\text { also act as an inflation hedge. }\end{array}$ & $\begin{array}{l}34 \text { per cent } \\
\text { increase in } 2019 \\
\text { compared to } 2010 .\end{array}$ \\
\hline
\end{tabular}

Source: Wahed Invest (2019)

stock, Sukuk and gold. Brief description of each portfolio is provided in Table 4.

The portfolios are further divided into six categories including very conservative moderate, moderately aggressive, aggressive and very aggressive. Wahedlnvest has allocated 97.50 per cent of its very conservative investment in Sukuk (Wahed Invest, 2019). The preferred securities selected for investment is the Franklin Global Sukuk Fund. The Franklin Global Sukuk Fund has an aim to maximize investment return by investing in either fixed or floating securities that are compliant with Shari'ah requirements (Franklin Templeton, 2019). However, 87.50 per cent of the very aggressive investment is allocated to global stocks, considering their growth potential as presented in Table 4. The preferred securities for global stocks are iShares MSCI World Islamic UCITS ETF.

\section{Case 2: Real Estate Islamic Crowdfunding}

EthicsCrowd, an Indonesia based crowdfunding platform, offers propertybased Islamic crowdfunding. The FSA Shari'ah committee has pronounced that the structure and mechanisms adopted by EthicsCrowd comply with Shari'ah requirements. However, the use of properties to invest crowdfund is identified as a factual matter and the Shari'ah committee advice to determine the Shari'ah compliance status on a case by case basis. The Mudharabah funding arrangement adopted by EthicsCrowd is also found to be Shari'ah compliant. As of 2019, the Islamic crowdfunding platform has involved 27,092 investors to transform the community by building affordable houses and allowing a poor segment of the community to fight against

IJIEF: International Journal of Islamic Economics and Finance, 3(1), 75-94 | 86 
Hasan, Hassan, \& Aliyu | Fintech, Blockchain and Islamic Finance: Literature Review and Research Agenda

poverty. The value of Islamic crowdfunding investment has grown to USD $7,200,696$ which covers 65 countries around the world.

This crowdfunding platform also utilizes Istisna and Murabahah structure for crowdfunding investment. The Istisna structure begins with the appointment of the crowdfunding agent by the project developer. In the second step, the investor appoints an agent to exercise an Istisna contract with developed undertaking a housing project. After securing necessary legal permission to continue with the project, the investor transfers the investment $t$ the agent. The agent, after receiving the fund from the investor, is responsible to make payment to the project developer according to the attunements specified in the contract. The Istisna contract is concluded upon completion of the completion of construction and disbursement of remaining sales price to the developer by the agent.

In the case of the Murabahah contract, the agent is responsible to appoint the developer of the housing project. The developer is responsible identify potential buyers to sell housing units upon completion. Bank Indonesia and Bank BTN Syariah play a major role as the developer is required to follow their requirement while completing the sale of the units. Proceed from the sale are shared between the agent and the developer. Upon receipt of the sales proceeds, the agent transfers to the investor according to the agreed profit sharing ratio.

\section{Islamic Fintech - Challenges and Research Agenda}

The financial sector has received the necessary boost with the introduction of Fintech, which is a combination of financial technology and services offered by financial institutions. Fintech firm, in general, is posing challenges to the conventional financial institutions by offering innovative services to a wide variety of consumers. Recent Fintech innovations have disrupted ordinary ways of banking and finance. Islamic financial institutions (IFIs) are also facing challenges from Fintech start-ups. Blockchain technology has introduced alternative currencies which are complicating the operations of traditional financial institutions.

The Islamic finance industry can benefit significantly by incorporating blockchain and other Fintech based technologies with their product offering. However, such integration of Fintech with Islamic finance industry would require improved monitoring to maintain the complex relationship between agents and key stakeholders. Absence of such monitoring would give rise to trust issues which is evident with all new technologies. Fintech based 
Hasan, Hassan, \& Aliyu | Fintech, Blockchain and Islamic Finance: Literature Review and Research Agenda

solution providers are faced with the challenge of increased scrutiny from various governmental bodies.

This is one of the major challenges and both Fintech solution providers and regulator have to work on a common solution to allow the efficient application of such innovation in the Islamic finance industry. Another challenge affecting the integration of Fintech with Islamic finance is the lack of understanding among stakeholders which can be attributed to the abstract nature of Fintech based technologies. Underdevelopment of the ecosystem of several Fintech infrastructures is limiting a comprehensive understanding of its capabilities and also affecting its market progression.

In addition, Fintech based solutions are affected by security and privacy issues. Finally, the major challenge toward successful integration of Fintech in Islamic Finance is the view of several Shari'ah scholars that Fintech innovation such as bitcoin and other cryptocurrencies are non-complying with Shari'ah. Therefore, the successful integration of Fintech technologies in the Islamic finance industry would require developing a set of standards that can ensure Shari'ah compliance nature of the products offered. Future research can focus on developing the areas to be covered while setting those standards and unveiling effective ways to monitor Fintech transactions to enhance stakeholder trust. In addition, it is important to explore the possible application of Fintech in Islamic finance that can improve the competitiveness of Islamic finance products as compared to products offered by the conventional financial industry.

We should also acknowledge that the growth of Islamic Fintech based startups creates pressure on the market share in the global Islamic economic industry. Islamic Fintech firms, with their niche offerings, are able to provide services which are appealing to untapped segments of Muslim societies where IFIs have yet to reach due to their operational and regulatory restrictions. Islamic Fintech firms have allowed access with a click of the button and Islamic crowdfunding platforms are serving as a meeting place where investors can directly contact their debtors and monitor the progress of the project from the beginning. Thus, Islamic Fintech firms have increased the need for transparency and accountability among IFIs.

However, Islamic Fintech firms are facing challenges with regards to reporting and Shari'ah compliance. While several Islamic fintech firms have managed to ensure satisfactory level of Shari'ah compliance by adhering to globally accepted Shari'ah standards prescribed by regulatory bodies such as Accounting and Auditing Organization for Islamic Financial Institutions (AAOIFI) and Islamic Financial Services Board (IFSB), majority of the Islamic Fintech firms have yet to meet such standards. In addition, Islamic Fintech firms are not following any uniform reporting standards which often 
Hasan, Hassan, \& Aliyu | Fintech, Blockchain and Islamic Finance: Literature Review and Research Agenda

evaluation of their performance and efficiency difficult for shareholders. In addition, Islamic Fintech start-up firms might need to review their internal and external governance mechanisms to ensure the long-term sustainability of their operations.

\section{Conclusion}

Islamic Fintech has the potential to disrupt all aspects of the industry. It has the potential to mirror the growth of the global Fintech ecosystem and improve the Shari'ah compliant nature of business and consumer financing. The growth of Islamic Fintech is driven by government initiatives, startups and customers, creating an efficient value chain. Government efforts can play a vital role in the development of Islamic Fintech ecosystem and recent initiative by organizations such as Dubai International Finance Center (UAE), Malaysia Digital Economy Cooperation (Malaysia), Bahrain Fintech Bay (Bahrain) and Financial Services Authority (Indonesia) is ensuring a promising future for the industry. Moreover, there is a demand for digital technologybased product offering among Muslim consumers which is expected to rise in the coming future. In such a situation, Islamic Fintech has a lot of potentials to ensure Shari'ah compliant products are available for the global market which can improve the competitiveness of the industry and its product offerings. Growth of the Islamic fintech, however, will require the development of appropriate Shari'ah standards by relevant regulatory bodies. In addition, reporting and governance standards applicable to Islamic fintech can improve the operational efficiency and transparency of Islamic fintech firms. Central banks of several jurisdictions, for example, the Central Bank of Bahrain, Bank Indonesia and Bank Negara Malaysia have taken steps to develop necessary standards to ensure effective monitoring of Islamic fintech firms. We have made an attempt to provide necessary direction to the regulators and academicians by addressing major challenges in the development of Islamic fintech from a global perspective. Findings provided by this study is expected to shed new light in this relatively new field of research.

IJIEF: International Journal of Islamic Economics and Finance, 3(1), 75-94 | 89 
Hasan, Hassan, \& Aliyu | Fintech, Blockchain and Islamic Finance: Literature Review and Research Agenda

\section{References}

Abojeib, M., \& Habib, F. (2019). Blockchain for Islamic Social Responsibility Institutions. In Fintech as a Disruptive Technology for Financial Institutions (pp. 221-240). IGI Global.

Abu-Bakar, M. M. (2018). Shari'ah Analysis of Bitcoin, Cryptocurrency and Blockchain.

Abubakar, M., Hassan, M. K., \& Haruna, M. A. (2019). Cryptocurrency Tide and Islamic Finance Development: Any Issue?. Disruptive Innovation in Business and Finance in the Digital World (International Finance Review, Vol. 20), Emerald Publishing Limited, 189-200.

Abubakar, Y. S., Ogunbado, A. F., \& Saidi, M. A. (2018). Bitcoin and its Legality from Shari'ah Point of View. SEISENSE Journal of Management, 1(4), 13-21.

Aisyah, M. (2018). Islamic bank service quality and its impact on Indonesian customers' satisfaction and loyalty. Al-lqtishad Journal of Islamic Economics, 10(2), 367-388.

As-Sidq. (2020). Why As-Sidq? Retrieved January 4, 2020, from https://www.assidq.com/home

Baber, H. (2019). Fintech, Crowdfunding and Customer Retention in Islamic Banks. Vision, 1-19. https://doi.org/10.1177/0972262919869765

Bakar, D. (2018). Is Cryptocurrency Haram? The Chairmain Of BNM's Shari'ah Advisory Council Says No. Retrieved July 11, 2019, from https://vulcanpost.com/632153/haram-cryptocurrency-syariahadvisory-council/. Accessed on 8/8/2018.

Beik, I. S., \& Arsyianti, L. D. (2008). Why the rate of financing in Islamic Banks is high? An analysis based on the Malaysian case. Tazkia Islamic Finance and Business Review, 3(1).

Biancone, P. P., \& Radwan, M. (2019). Social finance and financing social enterprises: an Islamic finance prospective. European Journal of Islamic Finance., Special Is, 1-7.

Biancone, P. P., Secinaro, S., \& Kamal, M. (2019). Crowdfunding and Fintech: business model sharia-compliant. European Journal of Islamic Finance, 12.

Dubai Islamic Economy Development Centre. (2018). Islamic Fintech Report 2018.

Elasrag, H. (2019). Blockchains for Islamic finance: Obstacles \& Challenges. Munich Personal RePEc Archive, (03), 1-39.

EthicsCrowd. (2019). Make money while circulating good. Retrieved July 5, 2019, from https://www.ethiscrowd.com/

IJIEF: International Journal of Islamic Economics and Finance, 3(1), 75-94 | 90 
Hasan, Hassan, \& Aliyu | Fintech, Blockchain and Islamic Finance: Literature Review and Research Agenda

Evans, C. (2015). Bitcoin in Islamic banking and finance. Journal of Islamic Banking and Finance, 3(11), 1-11.

Franklin Templeton. (2019). Franklin Global Sukuk Fund. Retrieved July 9, 2019, from https://www.franklintempleton.lu/investor/products/overview/16214/ 2Y/franklin-global-sukuk-fund

Gomber, P., Kauffman, R. J., Parker, C., \& Weber, B. W. (2018). On the Fintech revolution: interpreting the forces of innovation, disruption, and transformation in financial services. Journal of Management Information Systems, 35(1), 220-265.

Haruna, M. A., Abubakar, M., Hassan, \& M. K. (2019). Precious Metal Backed Crypto Currency Transactions: Applications in Islamic Finance, International Conference at Effat University, Saudi Arabia.

Ibrahim, M. A., Fisol, W. N. M., \& Haji-Othman, Y. (2017). Customer intention on Islamic home financing products: an application of the theory of planned behaviour (TPB). Mediterranean Journal of Social Sciences, $8(2), 77-86$.

Iqbal, A. (2012). Liquidity risk management: a comparative study between conventional and Islamic banks of Pakistan. Global Journal of Management and Business Research, 12(5).

Irfan, H., \& Ahmed, D. (2019). Fintech: The opportunity for Islamic finance. In Fintech in Islamic Finance. In Fintech in Islamic Finance -Theory and Practice (pp. 19-30). Routledge.

Irwin, A. S., \& Milad, G. (2016). The use of crypto-currencies in funding violent jihad. Journal of Money Laundering Control, 19(4), 407-425.

Jamil, N. N., \& Seman, J. A. (2019). The Impact of Fintech On The Sustainability Of Islamic Accounting And Finance Education In Malaysia. Journal of Islamic, Social, Economics and Development, 4(17), 74-88.

Kahf, M. (2015). Fatwa on Bitcoin. Retrieved July 9, 2019, from http://lightuponlight.com/blog/fatwa-on-bitcoin-by-monzer-

kahf/\%0Aretrieved on 08/08/2018.

Khan, I. (2017). OneGram: A Shari'ah Compliant and Gold Backed Digital Token.

Khan, M. N. A. A., \& Ismail, N. A. (2011). The Level of Internet Financial Reporting of Malaysian Companies. Asian Journal of Accounting and Governance, 2, 27-39.

Krippendorff, K. (2013). Content Analysis: An Introduction to Its Methodology (3rd edition). CA: Sage Publications.

Lacasse, R. M., Lambert, B., \& Khan, N. (2017). Blockchain TechnologyArsenal for a Shari'ah-Compliant Financial Ecosystem. Journal of

IJIEF: International Journal of Islamic Economics and Finance, 3(1), 75-94 | 91 
Hasan, Hassan, \& Aliyu | Fintech, Blockchain and Islamic Finance: Literature Review and Research Agenda

Business and Economics, 1-12.

Lacasse, R. M., Lambert, B., \& Nida, K. H. A. N. (2018). Islamic BankingTowards a Blockchain Monitoring Process. Revue de Gestion et d'Économie, 6(1-2), 33-46.

Lee, I., \& Shin, Y. J. (2018). Fintech: Ecosystem, business models, investment decisions, and challenges. Business Horizons, 61(1), 35-46.

Loo, R. V. (2018). Making innovation more competitive: the case of Fintech. UCLA Law Review, 65, 232.

Meera, A. K. M. (2018). Cryptocurrencies From Islamic Perspectives: The Case Of Bitcoin. Bulletin Of Monetary Economics and Banking, 20(4), 118

Morrison, A., Polisena, J., Husereau, D., Moulton, K., Clark, M., Fiander, M., ... Rabb, D. (2012). The effect of English-language restriction on systematic review-based meta-analyses: a systematic review of empirical studies. International Journal of Technology Assessment in Health Care, 28(2), 138-144.

Muedini, F. (2018). The compatibility of cryptocurrencies and Islamic finance. European Journal of Islamic Finance, 10, 1-11.

Muneeza, A., Arshad, N. A., \& Arifin, A. T. (2018). The Application of Blockchain Technology in Crowdfunding: Towards Financial Inclusion via Technology. International Journal of Management and Applied Research, 5(2), 82-98.

Oziev, G., \& Yandiev, M. (2018). Cryptocurrency from Shari'ah perspective. Retrieved from https://papers.ssrn.com/sol3/papers.cfm?abstract_id=3101981, on 20/07/2018.

Saad, M. A., \& Fisol, W. N. bin M. (2019). Financial Technology (Fintech) Services In Islamic Financial Institutions. In International Postgraduate Conference (pp. 1-10).

Stechemesser, K., \& Guenther, E. (2012). Carbon accounting: a systematic literature review. Journal of Cleaner Production, 36(2012), 17-38.

Tieman, M., \& Darun, M. R. (2017). Leveraging blockchain technology for halal supply chains. Islam and Civilisational Renewal, 8(4), 547-550.

Todorof, M. (2018). Shari'ah-compliant Fintech in the banking industry. ERA Forum, 19(1), 1-17.

Wahed Invest. (2019). The efficient way to invest. Retrieved July 7, 2019, from https://wahedinvest.com/portfolio/

Zavolokina, L., Dolata, M., \& Schwabe, G. (2017). Fintech transformation: how IT-enabled innovations shape the financial sector. In FinanceCom

IJIEF: International Journal of Islamic Economics and Finance, 3(1), 75-94|92 
Hasan, Hassan, \& Aliyu | Fintech, Blockchain and Islamic Finance: Literature Review and Research Agenda

2016 (pp. 75-88). Springer, Cham.

IJIEF: International Journal of Islamic Economics and Finance, 3(1), 75-94 | 93 
Hasan, Hassan, \& Aliyu | Fintech, Blockchain and Islamic Finance: Literature Review and Research Agenda

This page is intentionally left blank

IJIEF: International Journal of Islamic Economics and Finance, 3(1), 75-94 | 94 